\title{
SLC7A6 Gene
}

National Cancer Institute

\section{Source}

National Cancer Institute. SLC7A6 Gene. NCI Thesaurus. Code C118992.

This gene is involved in the transport of dibasic amino acids. 